\title{
GROWTH AND DISTRIBUTION IN THE MARKET ECONOMIES OF EAST ASIA
}

\author{
By GARY S. FIELDS
}

Irma Adelman and Sherman Robinson, Income Distribution Policy in Developing Countries. New York: Oxford University Press, I979, 346 pp., \$1 2.50.

Edward K. Y. Chen, Hyper-Growth in Asian Economies: A Comparative Study of Hong Kong, Japan, Korea, Singapore, and Taiwan. New York: Holmes \& Meier, 1979, 24I pp., \$36.oo.

John C. H. Fei, Gustav Ranis, and Shirley W. Y. Kuo, Growth with Equity:

The Taiwan Case. New York: Oxford University Press, 1980, 422 pp., \$19.95 (\$8.95 paper).

Walter Galenson, ed., Economic Growth and Structural Change in Taiwan. Ithaca, N.Y.: Cornell University Press, 1979, \$32.50.

Ronald Hsia and Laurence Chau, Industrialisation, Employment and Income Distribution. London: Croom Helm, 1978, 205 pp., \$21.50.

Felix Paukert, Jiri Skolka, and Jef Maton, Income Distribution, Structure of Economy and Employment. London: Croom Helm, I98 I, I69 pp., \$35.00.

V. V. Bhanoji Rao and M. K. Ramakrishnan, Income Inequality in Singapore, 1966-1975. Singapore: Singapore University Press, 1980, I61 pp., \$20.00 (\$1 o.0o paper).

W

HO benefits how much from economic development? This question is at the forefront of current thinking among social scientists. In contrast to the last generation of development studies, which was oriented primarily toward macro questions such as economic growth and capital formation, the current generation of studies adopts a more micro character.' This redirection began in the late ig6os with attention to the problem of unemployment. The decade of the I97os witnessed an outpouring of studies on distributional problems. In this essay, I will review several books written by economists analyzing income distribution in one part of the world, East Asia. ${ }^{2}$ But before

\footnotetext{
' Good overviews of the shift in thinking may be found in Gustav Ranis, "Equity and Growth: New Dimensions of Development," Journal of Conflict Resolution, xIx (September 1975), 558-68, and Erik Thorbecke, "Three Decades of Development," mimeo (Cornell University, 1980).

${ }^{2}$ For references to studies of income distribution in other parts of the world, see Gary S. Fields, Poverty, Inequality, and Development (Cambridge and New York: Cambridge University Press, I980); Charles R. Frank, Jr. and Richard C. Webb, eds., Income Distribution and Growth in the Less-Developed Countries (Washington, D.C.: Brookings, 1977);

(C) 1982 by the Trustees of Princeton University

World Politics 0043-8871/82/010001-24\$01.20/I

For copying information, see contributor page.
} 
doing so, it is imperative to review various approaches that have been used to measure change in income distribution in the course of economic development: different measures may lead to fundamentally different judgments about the success or failure of economic growth; they may even raise the question whether, in a given context, development took place at all.

\section{$\mathrm{II}^{3}$}

Table I presents three ways of measuring who benefits from economic development. Each approach is currently used in empirical studies of income distribution and economic development.

Example $I$ indicates changes that take place in two hypothetical economies, $A$ and $B$. Both economies start out in the same situation. Over an arbitrary interval of time, economy $A$ achieves an economic growth rate of 9 percent, while $B$ 's growth rate is 18 percent. Had these hypothetical facts been presented in the 1950 or or 1960 s, most readers would have regarded country $B$ as having achieved a better performance. In the I980s, however, we have been sensitized to think that distributional issues are important. The remaining columns in Example I present the usual kind of distributional data. The income share of the poorest $4^{\circ}$ percent of the population measures equality; the Gini coefficient measures inequality. In this example, the income share of the poorest goes down and the Gini coefficient goes up. Thus, in both $A$ and $B$, inequality rises. But the increase in inequality is greater in $B$ than in $A$. Thus, the economy with the faster growth rate registers a greater increase in inequality in income distribution. Considering this information, whose path of development would you chose- $A$ 's or $B$ 's?

Example 2 presents hypothetical data for two economies, $C$ and $D$. In both countries, Io percent of the labor force initially worked in highwage jobs and 90 percent in low-wage jobs. After a period of time, 20 percent of the labor force in country $C$ is in high-wage jobs, while in country $D$ the percentage in high-wage jobs has jumped to 30 percent. In other words, country $C$ increased the number of high-wage jobs by

William R. Cline, "Distribution and Development: A Survey of the Literature," Journal of Development Economics, I (July 1975), 359-400; William Loehr and John Powelson, The Economics of Development and Distribution (New York: Harcourt, Brace, Jovanovich, 1981); and the references cited in these books.

3 This section is drawn from Fields (fn. 2). For other discussions of measuring income distribution, see Amartya Sen, On Economic Inequality (New York: Norton, 1973); Anthony B. Atkinson, The Economics of Inequality (Oxford: Oxford University Press, 1975); and Nanak C. Kakwani, Income Inequality and Poverty (New York: Oxford University Press, 1980). 
Ioo percent, whereas country $D$ achieved a 200 percent increase. Considering this information, whose path of development would you choose-C's or D's?

Example 3 shows, for two hypothetical economies, $E$ and $F$, the average absolute income of the poorest 40 percent of the population. Both initially and later, the poor average an income of $\$ 40$ per week. Considering this information, whose path of development would you choose-E's or $F$ 's?

Most persons who were asked these questions found Example I difficult: although $B$ 's record of economic growth is better than $A$ 's, rel-

\section{TABLE I}

Three Ways of Measuring Who Benefits from Economic Development

EXAMPLE I

\begin{tabular}{ccc}
$\begin{array}{c}\text { Growth of } \\
\text { National } \\
\text { Income }\end{array}$ & $\begin{array}{c}\text { Income Share } \\
\text { of Lowest 40\%: }\end{array}$ & Gini Coefficient \\
\cline { 4 - 4 } & Level \% Change & Level \% Change
\end{tabular}

Both countries

initially

Country $A$

later

Country $B$

$\begin{array}{llllll}\text { later } & 18 \% & 0.307 & -15 \% & 0.162 & +97 \%\end{array}$

EXAMPLE 2

\section{Percentage of Labor Force in:}

High-Wage Jobs Low-Wage Jobs Rate of Growth of

$($ Real Wage $=\$ 2) \quad($ Real Wage $=\$ 1) \quad$ High-Wage Jobs

\begin{tabular}{llll}
\hline $\begin{array}{l}\text { Both countries } \\
\text { initially }\end{array}$ & $10 \%$ & $90 \%$ & \\
$\begin{array}{l}\text { Country C } \\
\text { later }\end{array}$ & $20 \%$ & $80 \%$ & $100 \%$ \\
$\begin{array}{l}\text { Country } D \\
\text { later }\end{array}$ & $30 \%$ & $70 \%$ & $200 \%$ \\
\hline
\end{tabular}

EXAMPLE 3

Absolute Income of Poorest $40 \%$ of Population*

Both countries initially

Country $E$ later $\$ 40$

Country $F$ later

$\$ 40$

* Assuming a 40-hour work week at $\$$ I per hour.

Source: Fields (fn. 2). 
ative income inequality grew worse in $B$ than in $A$; this fact weighs negatively. Those who dislike inequality a great deal preferred $A$ to $B$; those who are only mildly averse to inequality chose $B$. Example 2 posed little trouble: $D$ created twice as many high-wage jobs as $C$. The issue seems clearcut. As for Example 3, there seems to be no choice. Neither $E$ nor $F$, it appears, registered any improvement. To summarize the answers to these questions:

Example I: respondents are about equally divided between $A$ and $B$. Example 2: respondents are nearly unanimous in preferring $D$.

Example 3: respondents cannot choose; $E$ and $F$ seem identical.

In fact, $A, C$, and $E$ are the same country, and $B, D$, and $F$ are the same country. The respective income distributions, assuming io income recipients in each, are:

Initially in both countries: ( $\mathrm{I}, \mathrm{I}, \mathrm{I}, \mathrm{I}, \mathrm{I}, \mathrm{I}, \mathrm{I}, \mathrm{I}, \mathrm{I}, 2)$

Later in $A-C-E$ :

(I, I, I, I, I, I, I, I, 2, 2)

Later in $B-D-F$ :

(I, I, I, I, I, I, I, 2, 2, 2)

The point of this example is that the measure of income distribution may be vitally important in reaching qualitative judgments. Real-world economic development and policy projections are often presented in these ways. The difference, therefore, lies in the presentation of the data.

The measures of income distribution in common use fall into three general classes, which are illustrated by the three examples. Measures of relative inequality compare the income of various groups to that of others. Measures of absolute income indicate how many income recipients have how much income; a subset of the measures of absolute income are the measures of absolute poverty; they define an income figure below which a recipient unit is poor, and then measure the number of poor and the average income received by them. Measures of relative poverty define a fixed proportion as poor (say, the poorest 4 ? percent) and gauge the absolute income of this fixed proportion.

Which type of measure should be used? This question must be answered conditionally. The "right" type of measure depends on the interest of the analyst. If one believes, as I do, that the most important distributional problem in less developed countries is that the poor lack sufficient resources to feed and clothe themselves and to avoid disease, one will think of distributional issues in terms of absolute income or absolute poverty. In that case, the data that should receive the greatest weight are the number of poor and the extent of their income shortfall. 
On the other hand, the problem may be perceived differently: great weight may be given to the subjective feelings of the poor, in that the principal problem of poverty occurs when the economic positions of some are improving and others are left behind. If the importance of relative deprivation is the main consideration, one will use measures of relative inequality such as the income share of the poorest 40 percent, or the Gini coefficient. However, one should not combine a concern over the absolute economic misery of the poor with measurements of relative inequality: if one assigns heavy weight to changes in the usual measures of relative income inequality and interprets rising inequality as offsetting the economic gains brought about by growth, one may inadvertently overlook important progress toward the alleviation of poverty.

Does this theoretical possibility reflect an empirical reality? The answer is a clear "yes." Figure I summarizes evidence on changes in relative inequality and absolute poverty for a dozen less developed countries. We observe five cases in which income distribution improved when measured by both absolute poverty and relative inequality, and two other cases in which income distribution worsened when measured by both. We thus have seven cases of qualitative disagreement between the two approaches - a bare majority. In the other five cases, the measures of relative inequality and absolute poverty give qualitatively different impressions. In four of them, absolute poverty diminished but relative inequality widened; in the fifth, inequality narrowed but poverty worsened. Clearly, the choice of measure matters empirically as well as theoretically. To repeat, the choice of measure should be guided by what one believes to be the most salient feature of poverty.

To sum up this section: income distribution may be gauged according to measures of absolute income and poverty, relative inequality, or relative poverty. Not only theoretically, but also in the economic histories of a number of developed countries, the various measures may give quite different qualitative indications of who is benefiting from economic development. The type of measure used should be determined by the phenomenon of greater concern to the analyst-absolute economic misery or relative economic deprivation.

\section{III}

In turning to the patterns of change in income distribution in Asia, an excellent starting point is Edward K.Y. Chen's Hyper-Growth in 


\section{Figure I}

Changes in Relative Inequality and Absolute Poverty in Twelve LDCs

\begin{tabular}{|c|c|c|}
\hline & $\begin{array}{l}\text { ABSOLUTE } \\
\text { POVERTY } \\
\text { DECLINED }\end{array}$ & $\begin{array}{l}\text { ABSOLUTE } \\
\text { POVERTY } \\
\text { INCREASED }\end{array}$ \\
\hline $\begin{array}{l}\text { RELATIVE } \\
\text { INEQUALITY } \\
\text { DECLINED }\end{array}$ & $\begin{array}{l}\text { Costa Rica, I96I-I97 I } \\
\text { Pakistan, I963/I964- } \\
\text { I969/ı } 970 \\
\text { Singapore, I966-1 } 975 \\
\text { Sri Lanka, I953-I973 } \\
\text { Taiwan, I964-I972 }\end{array}$ & $\begin{array}{l}\text { India, I960/I96 I- } \\
\text { I968/I969 }\end{array}$ \\
\hline $\begin{array}{l}\text { RELATIVE } \\
\text { INEQUALITY } \\
\text { INCREASED }\end{array}$ & $\begin{array}{l}\text { Bangladesh, I963/1964- } \\
\text { I 973/I } 974 \\
\text { Brazil, I } 960-\text { I } 970 \\
\text { Mexico, I963-1969 } \\
\text { Puerto Rico, I953-1963 }\end{array}$ & $\begin{array}{l}\text { Argentina, I953-196I } \\
\text { Philippines, I 96I-I } 197 \text { I }\end{array}$ \\
\hline
\end{tabular}

Asian Economies. This book examines the contours and patterns of economic growth, the causes of growth (including foreign trade and exports), and the effects of growth, especially those of income distribution. Chen offers institutional description, factual detail, and economic analysis in just the right proportions. Perhaps not all economists would agree with all of his analytical methods. Nonetheless, social scientists from all disciplines, including economics, can learn from this study how the rate and character of economic growth shaped the patterns of income distribution in these countries, why poverty diminished rapidly in each of them, and why inequality fell in all of them except Japan.

Chen is an enthusiastic champion of market economies. He reaches six conclusions about how "the smooth working of the price mechanism in our group of economies has produced favourable effects" (p. I83). The first five involve the causes of growth:

I. Substantial increases in factor inputs are required for rapid economic growth (p. I 83).

2. Entrepreneurs play the most important part in mobilizing and directing resources for both production and research and development activities (p. I 83).

3. The large amount of capital required for investment was made possible by the high rates of domestic savings in these economies (p. I 84 ).

4. In all the economies under study, a continuous supply of labour was somehow available to the industrial sector (p. I 84 ).

5. Export growth is the necessary and sometimes the sufficient condition for rapid growth (p. I85). 
The last conclusion concerns the distribution effects of growth:

6. With the exception of Japan, rapid growth in our economies was generally accompanied by increasing equality in income distribution. Thus, growth under the working of the free forces of demand and supply is not necessarily associated with increasing equality, as many critics of the market economy would assert. There is however no strong evidence to support the view that growth under the working of the price mechanism will necessarily increase equality in income distribution, as to a large extent historical and institutional factors coupled with appropriate government policies are important in determining income distribution in the economies under study (pp. 185-86).

The view that the income-distribution experiences of countries depend on the growth setting and on government policy, and that reliance on the price mechanism is good for both aggregate growth and distributional goals, is a recurrent theme in the books under review. In recent works on Taiwan, the virtues of market-oriented growth are further elaborated.

Two books on Taiwan provide a wealth of material on distributional aspects of that country's experience with economic development. Growth with Equity, by Fei, Ranis, and Kuo, is concerned with the changing income inequality in Taiwan's growth experience. By contrast, Economic Growth and Structural Change in Taiwan, edited by Walter Galenson, addresses employment and many other features pertaining to economic well-being, but almost ignores income distribution. These two books are excellent complements to one another. Readers seeking to understand an economic success story would be well advised to study both.

The Fei-Ranis-Kuo volume has four objectives:

I. Analysis of the character of Taiwan's growth and its effects on income distribution.

2. Elaboration of a methodology for decomposing income inequality and analyzing change in income inequality.

3. Empirical implementation of the decomposition methodology.

4. Breakdown of wage-income inequality.

The authors are most successful with the first of these tasks. They maintain that the key ingredients in Taiwan's experience were an initially favorable asset distribution (because of fundamental land reform in the early 1950s), major attention to agriculture and rural development, timely export substitution (i.e., the switch from land-based exports to the exportation of products manufactured mainly by unskilled 
labor), and reliance on market incentives and signals. Their analysis is sensitive and thoughtful, reflecting their stature in the field of development economics.

The decomposition methodologies they develop are ingenious. Lamentably, however, the empirical implementation of these methodologies is flawed by the authors' use of inappropriately aggregated data. They are aware of this problem; in fact, one of them (Fei) is co-author of a paper that uses disaggregated data to make major changes in key numbers underlying some of the decomposition results. ${ }^{4}$ The outcome of the empirical decomposition studies in the Fei-Ranis-Kuo book should be weighed in light of the findings of the Pyatt-Chen-Fei paper.

One finding in Fei-Ranis-Kuo that does stand up even after disaggregation is that inequality of labor incomes is the most important contributor to total income inequality in Taiwan. This conclusion is important, since it focuses attention on inequality of labor incomes. That is where the attention belongs, rather than on functional distribution of income, which too often is at the center of development studies. Fei, Ranis, and Kuo are to be applauded for taking the next step and examining the correlates of labor income inequality in detail. It would have been useful if they had availed themselves of the more familiar and less cumbersome methods used by labor economists to estimate earnings functions.

In sum, the Fei-Ranis-Kuo volume contains a skillful inductive analysis of the effects of economic growth on income inequality in Taiwan, buttressed by ample macroeconomic and income-distribution statistics; the development of an innovative methodology for decomposing income inequality and its change over time; and a problematical empirical implementation of the decomposition procedures. The authors state their own criterion for success:

The linkage between the family distribution of income and the theory of growth, and the conclusions for theory and policy which can be derived from the inductive examination of the Taiwan experience, thus constitute the focal points of this volume. We clearly have not solved the problem. Indeed we shall be pleased if it is judged that we have somewhat advanced the cause (p. xix).

Indeed they have.

Economic Growth and Structural Change in Taiwan includes chapters by Simon Kuznets, Erik Thorbecke, Gustav Ranis, Erik Lundberg,

${ }_{4}$ Graham Pyatt, Chau-Nan Chen, and John C. H. Fei, "The Distribution of Income by Factor Components," Quarterly Journal of Economics, Vol. 94 (November, I980), 45 I-73. 
Maurice Scott, Ian Little, and Galenson himself. A subsequent paper by Galenson, written with his customary clarity and force, synthesizes the book's major conclusions. 5 They may be summarized as follows:

I. Economic growth is a necessary condition for the alleviation of poverty.

2. Capital formation is necessary for growth.

3. To devote more resources to capital formation, countries must delay providing for the poor until future generations.

4. Taiwan achieved high rates of capital formation and economic growth by creating an environment with incentives that reward successful innovation and hard work.

5. The result was that poverty fell greatly in one generation.

These propositions are not entirely uncontroversial. I would disagree with the first one by citing Sri Lanka as a case where absolute poverty was demonstrably reduced despite a low rate of economic growth. ${ }^{6}$ I also am less willing than Galenson to conclude that it is desirable to wait until the next generation to see poverty substantially lessened; nor do I think this policy, if openly debated, would stand much chance of being implemented except under authoritarian conditions. I agree with Galenson's basic theme-that Taiwan was successful in alleviating poverty and achieving widespread improvements in standards of livingthough I regard data on changes in absolute poverty as more compelling than the social indicators provided in Galenson's study.?

Four other books on income distribution in East Asia bear mention. Two of them-Income Inequality in Singapore, by Rao and Ramakrishnan, and Industrialization, Employment and Income Distribution by Hsia and Chau-have as their objective the statistical analysis of changes in income distribution in Singapore and Hong Kong, respectively. The authors examine income inequality within and between various economic sectors, occupations, and socioeconomic groups. In both economies, shifts of population from categories of relatively high inequality to those of relatively low inequality are held to be responsible for a decrease in inequality. Readers who wish to know about such structural changes will appreciate these books. But readers who wish to look behind these changes for a thoroughgoing analysis of how the two small island economies achieved rapid improvements in growth and

\footnotetext{
5 Galenson, "How to Develop Successfully: The Taiwan Model," paper prepared for the Conference on Economic Development in Taiwan, December 1981.

${ }^{6}$ See the Sri Lanka case study in Fields (fn. 2), chap. 6.

7 Compare Table 6.19 in Fields, ibid., with Table 7 in Galenson (fn. 5).
} 
distribution through labor-intensive industrialization aimed at the world market will have to find their answers elsewhere.

Two other books simulate interrelationships between income distribution and the rest of the economy. In Income Distribution, Structure of Economy and Employment, Paukert, Skolka, and Maton ask how counterfactual changes in income distribution would affect employment and other economic variables. By building an input-output model to estimate these effects for four countries, they find substantial impacts for the Philippines, Malaysia, and Iran, but only minor ones in Korea. My major problem with their work is that I question the very idea of simulating the effects of exogenous changes in income distribution. A country's income distribution is not exogenous. It is determined by employment opportunities, wage structure, and a host of other factors. It might be more useful to posit changes in policy variables such as taxes, subsidies, and development strategies, and simulate their effects on income distribution and other economic variables.

That is what Irma Adelman and Sherman Robinson do in Income Distribution Policy in Developing Countries. Their major finding is that

the time path of the size distribution of income is exceedingly stable.... Only when a sufficient number of different interventions are applied simultaneously, so that there is, in effect, a change in development strategy, are more sizable or lasting effects possible" (p. 17).

Whether the income distribution is in fact stable is a matter of perception, based in large part on the measurement tool used. Though the Lorenz curve, the Gini coefficient, or the income share of the poorest 20 percent may change little, substantial numbers of people may have large income gains or losses. For example, Adelman and Robinson report that land reform would raise the incomes of the bottom decile of the rural population by an estimated 28.7 percent and reduce the proportion of poor by one-third to one-half. ${ }^{8}$ I would not call this small. Nonetheless, I concur wholeheartedly in their judgment that development strategy is decisive in affecting the course of income distribution.

\section{IV}

There is much to be learned from the growth experiences of the newly industrializing countries of East Asia. Taiwan, Korea, Hong Kong, and Singapore have sought to produce for world markets. They

${ }^{8}$ I derive this poverty-reduction figure by comparing the $4.6 \%$ reduction of poverty (Adelman and Robinson, Table 53) with the $8.0 \%$ poverty rate using a 90,000-won poverty line and the $14.5 \%$ poverty rate using a line of 120,000 won (Adelman and Robinson, Table 39). 
have succeeded in raising national income, maintaining high levels of employment, multiplying real wages, lowering poverty, and narrowing income inequality. The message with which several of the authors would leave us is that "getting the prices right" in a market economy with a minimum of government interference is the way to achieve growth and distributional goals. While a market orientation may be one way to develop, we would also do well to heed Fei, Ranis, and Kuo:

True, few other developing countries have the same combination of a relatively favorable initial distribution of assets and a willingness to deploy the market mechanism effectively over time. But the experience in Taiwan does not support ... the argument that the market solution at every step of the way will, in the presence of powerful landed or industrial interests, yield the desired complementarity between the objectives of growth and equity (p. 310 ; emphasis added).

In a similar vein, Adelman and Robinson tell us:

Of the basic development strategies we have explored, two stand out as being potentially appropriate for equitable growth. The first is an intensification of the one that Korea has pursued, particularly in the 1964-73 decade: export-led, open, labor- and skill-intensive growth. A necessary condition for the success of this strategy in improving the income distribution and alleviating poverty is that a large proportion of the labor force be well educated or skilled workers. A second requirement for the success of this type of strategy is that the natural course of the agricultural terms of trade, when upward, should be reinforced (or at least not be impeded) and when downward should be reversed.... The second promising strategy is that of emphasizing rural development. Its success likewise depends on two conditions. The first of these is a relatively equal distribution of land and equitable tenure arrangements; the other is some kind of institutional arrangement for maintaining agricultural prices. These two strategies are not mutually exclusive.... The fact that the successful implementation of each of the two equitable growth strategies is predicated on the fulfillment of both a preexisting condition and a policy condition cannot be overemphasized. The application of these strategies to countries where the preexisting conditions are not met is likely to lead to the opposite result from that intended (p. 199; emphasis added).

And Galenson notes:

Adherence to the Taiwan model does not guarantee equal success. Malaysia, the Philippines, and Thailand, for example, are market economies with substantial investment rates, moderate inflation, and access to foreign markets. While they have not done badly, their economic growth rates have not matched that of Taiwan. Pinpointing the precise factors that made for the differences would make an illuminating study (p. 33).

Might the observations of Fei-Ranis-Kuo and Adelman-Robinson on the synergism between policy and initial conditions be the answer? 